\title{
FKUB's Communication Strategy in Mantaining Religious Harmony in Medan
}

\author{
Fauji Wikanda ${ }^{1}$, Mohd. Hatta ${ }^{2}$, Abdullah $^{3}$ \\ ${ }^{1,2,3}$ Postgraduate Program in Universitas Islam Negeri Sumatera Utara, Indonesia \\ wikanda_fauji@yahoo.com
}

\begin{abstract}
The objective of this study is to investigate communication strategies implemented by Forum Kerukunan Umat Beragama (Indonesian: Religious Harmony Forum) in maintaining religious harmony in Medan. The research used a qualitative descriptive analysis and a method of data collection which consisted of indepth interviews with research informants, interviews using observation techniques with direct field observation, and document study to explore data. Communication strategies implemented by Forum Kerukunan Umat Beragama (FKUB) in maintaining religious harmony in Medan include determining communicators based on the communicants' religion and ethnicity; grouping the target audience by adjusting the program's theme to the communicants' age, gender, education, work and religion; gathering informative, persuasive and educational messages; and utilizing printed, electronic and outdoor media.
\end{abstract}

Keywords

communication strategy, $\mathrm{F} \mathrm{KB}$ religious harmony

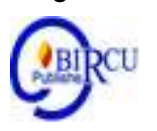

\section{Introduction}

Medan is one of the largest cities in Indonesia with a population of 2,210,624 inhabitants (Central Bureau of Statistics, 2018). The population, spreading in 21 districts and 151 villages, consists of a diversity of race, ethnicity, religion and ethnic groups. Uniquely, this heterogeneity becomes a terminology that gives meaning to the extraordinary social reality, raising public awareness of the difference and the need for unity and integrity.

Culturally, the people of Medan can be categorized into three groups: the indigenous people, which include the Malays (National Border Management Agency of North Sumatra, 2003), and the native ethnic groups of North Sumatra such as MandailingAngkola, Karo, Pakpak-Dairi, Simalungun, Toba Batak, and Nias; the migrants from local ethnic groups such as the Acehnese, Minang, Banjar, Sundanese, Javanese, Bugis, and Makassar; and the migrants of international ethnic groups such as Tamil, Punjab, Hindustani, Arabs, Hokkien, Khek, Hakka, Kwantung, and various European ethnic groups (Tengku Luckman Sinar, 1988).

From the social perspective, ethnic-based organizations bearing the names of their ethnicity are ubiquitous in Medan. They include MABMI (Majelis Adat Budaya Melayu Indonesia/ Malay Ceremony \& Cultural Assembly), HIKMA (Himpunan Keluarga Besar Mandailing/ the Association of Mandailing Families), HMKI (Himpuan Masyarakat Karo Indonesia/ Indonesian Karo Society Association), Pujakesuma (Putra Jawa Kelahiran Sumatera/ Javanese born in Sumatra), BM3 (Badan Musyawarah Masyarakat Minang/ Council of Minang Community Institution), HIMNI (Himpunan Masyarakat Nias Indonesia/Indonesian Nias Community Association), Aceh Sepakat, and so on. 
In addition, phrases or statements stereotyping one tribe or ethnic group are very much in circulation in Medan. Some examples of them are Gerobak Pasir (Gerombolan Batak Payah Diusir) addressed to those from Batak Toba; Biar Rumah Condong Asal Gulai Lomak addressed to the Malays, Padang Pancilok addressed to the Minangkabau, Karbus (Karo Busuk), Jabir (Jawa Birit), Manipol (Mandailing Politik) addressed to those from Angkola/Mandailing, and Aceh Pungo aimed at the Acehnese.

In terms of religions, Muslims makes up 59.68\% of the population in Medan, Protestant-Christians 21.16\%, Catholic 7.10\%, Hindu 2.15\%, Buddhism 9.90\%, and Konghuchu $0.01 \%$ (Population Census Data, 2015), with a total of 1,647 mosques, 691 churches, 39 Catholic churches, 157 Buddhist temples, and 23 Hindu temples (Population Census Data, 2010).

From the aspect of education, Medan has seen the mushrooming growth of religionbased educational institutions starting from kindergartens to universities, each with a mission to spread a particular religion. Apparently, almost all religions have been sustained with their distinctive educational institutions, and this fact has seized the attention of the government and religious communities in Medan. Even though these institutions also hire teachers or instructors with different religious adherence, their exclusivity is still clearly noticeable.

On the other hand, Medan is well-known as the city of tolerance, where the level of religious harmony among the believers is so well-mantained that it has drawn the national attention as a barometer or a model city in Indonesia. This is noticable from the recent visits of high profile figures, such as the Surakarta city government who visited in July 2018 to study the religious harmony and tolerance at FKUB Medan (http://www.medanbisnisdaily.com).

Medan also received an award from the Central Government during the 73rd Amal Bhakti MORA of the Republic of Indonesia in Medan International Convention Center (MICC) at Jalan Gagak Hitam, Medan (http://news.analisadaily.com). This certainly became a special achievement for FKUB in their effort to nurture and strengthen their function and role as a medium and a gathering place for the representatives of each religion in Medan. Under this organization's supervision, the diversity of religions can function as a major force in future development of Medan.

Nevertheless, a closer look into a few incidents taking places in Medan reveals that conflicts among religious communities are usually incited by the evictions of places of worship. These cases include the eviction of al Jihad Mosque in Pulo Brayan, al Khairiyah Mosque at Jalan Puteri Hijau, at Thayyibah Mosque at Jalan Multatuli, al Ikhlas Mosque at Jalan Timor, Roudhatul Islam Mosque next to the Emerald Garden Hotel at Jalan Puteri Hijau, and Amal Silaturrahim Mosque in Mega Mas Asia Complex areas. Also among the mosques that were almost evicted was Nurul Hidayah Mosque at Jalan Pancing. This mosque eviction was carried out by a non-Muslim (Buddhist) developer (http://da.analisadaily.com).

In addition, there was an attack on Muslim preacher Burhanudin Siagian in Taqwa Mosque, East Medan District by dozens of non-Muslims who were angered by the contents of his sermons on the night of January 26, 2017 (https://www.portal-islam.id). It began as Burhanuddin Siagian was delivering a sermon in Taqwa mosque in the district of East Medan. A crowd consisting of people living in the vicinity of the mosque were incited by Siagian's statement that the independence fighters of the Republic of Indonesia cried out takbir instead of halelluya. The mass of non- Muslims who overheard the sermons flocked to the mosque, swarming the mosque's courtyard and making the atmosphere tense.

This incident was immediately addressed by FKUB, and the government of Medan arrived at the location of the incident shortly after. After a dialogue was held, to avoid a 
further quarrel, a declaration of peace was held, and an agreement was signed by the two parties at Brayan Bengkel district office at Jalan Purwosari Komplek Wartawan, Medan.

Still, the case of mistreatment of a Madrasa teacher named Nursarianto by an Indonesian-Chinese occurred on February 7, 2019 (http://waspada.co.id). It was found out that Nursarianto had just returned from teaching at a madrasa at Jalan Mandailing, Bantan Timur Village, Medan Tembung District when he saw two madrasa students crying and running hastily because they were being chased by a dog. They even fell because they were afraid of being bitten by the dog. Witnessing the incident, Nursarianto stopped by at the dog owner's house. He reminded the dog owner not to allow his dog to roam around. Feeling offended, the dog owner scolded him back. He was infuriated and started beating up Nursarianto in the face. Seeing this, other residents swarmed to intervene. Afterwards, Nursarianto reported the incident to the authorities, and the police from Medan Police Resort Criminal Investigation secured the dog owner.

In a different location, a pig farm located at Jalan Tangguk Dismantling XI Perumnas Mandala II, Medan Denai sub-district also triggered a clash between two religious communities. There had been repeated reports from the residents of Perumnas Mandala voicing their objection to the farm operating in the residential areas. The local government had actually conducted several socializations to the farmers, but their warning was not well heeded. Therefore, the city government of Medan decided to reorganize the troubling ranch area, resulting in aturmoil between the municipal police unit and the pig farmers (https://www.antaranews.com).

There have also been cases of unauthorized development of places of worship (church) in Medan. For example, the Indonesian Bethel Church in the Filadelfia Congregation located at Jalan 4 Block 8 Griya Martubung No. 31, Kelurahan Besar; Medan District was stormed by the residents of the housing complex because it was allegedly a house converted into a church illegally (https://news.detik.com).

The most recent case was rock throwing at al Amin Mosque located at Jalan Belibis, Tegal Sari Mandala II Medan Denai Sub-District, Medan. On Friday, January 24, 2020 a group of people threw rocks at the mosque, damaging some parts of the mosque (https://digtara.com).

In the aftermath of that incident, a number of Muslim associations arriving to check on the condition of the mosque clashed with the alleged perpetrators of the vandalism. The police subsequently dispersed the clashing groups and a few days later arrested the alleged perpetrators, who admitted to have committed the rock throwing out of anger because of the forcible shutting-down of wine kiosk by the security forces.

The next case is a desecration of Quran by way of shredding and spreading the torn pieces on Sisingamangaraja Street, Medan. The perpetrator took the scripture from the Great Mosque of Al-Maksum, Medan and started tearing it down on their way escaping. The torn pieces of the scripture were scattered on Sisingamangaraja Street, Medan. This case was later successfully solved by the police (https://medan.tribunnews.com).

Furthermore, there was also a demonstration staged by pig breeders, restaurant owners, and pig farming supporters from Medan and a number of other egions in North Sumatra. The demonstration took place on February 10, 2020 in front of the House of Representatives of North Sumatra. The demonstrators strongly rejected the local government's plan to cull the pigs because they believed that pigs have an absolute, irreplaceable position for the Bataks (https://sumutpos.com).

The protesters also demanded that the government to find a solution to the ASF virus that was plagueing the pig farms in North Sumatera. They also urged the government to consider the loss they will suffer if the culling was carried out and to prepare swine fever 
virus vaccine without charging pig farmers. This case was purely an expression of disappointment against the provincial government in particular, but it had the potential to trigger a clash among religious communities in Medan.

The above cases demonstrate that religious harmony in Medan is beginning to fail. All the potential conflicts mentioned above could be resolved through communication and dialogue organized by FKUB with the aim of properly maintaining harmony and tolerance between religious communities in the city of Medan.

\section{Review of Literatures}

Hafied Cangara (2013) mentioned that at least four things had to be present in an applied communication strategy, namely: a strategy in determining communicators, a strategy in determining targets and analysis of audience needs, a strategy in organizing messages, and a strategy in selecting media and communication channels.

\subsection{Strategy in Determining Communicators}

According to studies on communication, communicators are the source and the controller of all communication activities. Thus, the main source of failure in communication is the communicator because he or she does not understand the organization of messages, the selection of the right media, and how to approach the target audience. There are three conditions a communicator must meet, namely: (1) credibility (the level of other people's trust in him or her), (2) attractiveness, and (3) power (Hafied Cangara: 2013).

\subsection{Strategy in Determining Targets}

An effort to understand the targeted audience in a communication program is highly important because all communication activities are directed at them. They will determine the success or failure of a program because no matter how much money, time, and energy spent to influence an audience, if they are not attracted to the program offered, the communication activities will be in vain (Hafied Cangara: 2013).

\subsection{Strategy in Organizing Messages}

A message is everything that is conveyed by someone in the form of a symbol that is perceived and accepted by the public in the activities of meaning. Symbols are the products of human invention that contain meaning used in communicating with others. Symbols are divided into verbal and non-verbal symbols. Non-verbal symbols are also called sign language, body language, or silent language. In message organization technique, the message delivered must be informative, persuasive, and educative (Hafied Cangara: 2013).

\subsection{Strategy in Media Selection}

In selecting communication media, communicators must consider the characteristics and the purpose of the contents of the message, as well as the type of media accessed by the targeted audience. The contents of the message must take into account the differences between messages intended for wider community and those targeting specific audience. For wider community, messages should be conveyed through mass media such as print media or television. As for certain communities, leaflets or group communication channels can be used (Hafied Cangara: 2013). 


\section{Research Methods}

This research was conducted as a qualitative descriptive research, in which the validity is interpreted as the level at which various concepts and interpretations proposed by a researcher correspond in terms of meaning to what is perceived by the subjects or study participants. Data collection techniques the researchers used in data collection for this study were in-depth interviews, interview, and document study. In the in-depth interviews, the researcher conducted comprehensive interviews to informants on the research problem. The choice of in-depth interview technique was based on fact that this research was focused on the subjects to whom communication strategies were directly applied in an effort to maintain harmony and tolerance among religious communities. Experience is a past event, and only indepth interviews can accommodate the data across time. In interview, the researcher used observation techniques by making direct field observations on the implementation of FKUB's communication strategies, especially on the forms of communication strategies, the media used in their implementation, as well as the obstacles in the application of the strategies. In the study of the document, the researcher collected the data by investigating the documents available in FKUB Medan such as books, bulletin, and other related documents.

The researcher used three techniques to ensure the validity and objectivity of the research data. First, the researcher prolonged the data collection duration in order to collect considerable corroborating evidence to ensure the compatibility between findings and the actual situation. Second, the researcher conducted triangulation in the data collection and analysis to verify and to ensure the accuracy of the data by comparing and contrasting information from different sources, particularly between the results of the interview and observation. Third, the researcher performed member checks by returning the data and the interpretation to the participants to verify in accordance with the meaning as they perceived.

\section{Discussion}

\subsection{FKUB Communication Strategy}

Based on the findings, the communication strategies applied by FKUB Medan are as follows:

\section{a. Strategies in Determining Communicators}

In the dialogues with interfaith leaders, female figures, worship place caretakers, religious trainers, teachers, youth, university and high school students, as well as neighborhood chiefs, FKUB implemented the strategy of determining communicators.

The implementation of this strategy was evident from FKUB's appointment of the communicators. FKUP determined their communicators by conforming their ethnicity, religions and competency to those of the communicants in the dialogues. When the dialogue was held, FKUB invited the representatives from each religion to have a discussion and Qand-A session. This was done in an effort to maximize the communication with interfaith figures and followers and to avoid social jealousy from certain religious groups.

FKUB also carried out their roles and functions as an agency licensing the establishment of places of worship. In this process, FKUB also implemented a communicator selection strategy in delivering their messages. For instance, when representatives of religious communities visited FKUB office and submitted a letter proposing the establishment of a place of worship, after file verification process, FKUB will send their representatives from 
the inspection team to the designated location of the place of worship. The team consisted of all religious representatives, coordinated by the representative from the religious community who proposed the establishment. If the Muslims submitted the permit to establish a place of worship, FKUB would deploy a team consisting of representatives of all religions coordinated by an FKUB Muslim representative.

Another form of communicator selection strategy was implemented by FKUB when conducting community programs such as interfaith sporting events, communal work, highschool writing contests, high-school speech competition, and high-school outbound training. The representatives of each religion were included in the committee who would guide the participants and deliver their opening remarks in the events. In addition, FKUB also appointed the jury from each participating religious community. This would psychologically have a positive impact on all participants.

Dissemination of information to the interfaith communities was conducted both verbally and non-verbally through lectures, dialogues, discussions and question-and-answer sessions conducted by means of direct, face-to-face communication. In every discussion and question-and-answer session, representatives of religious communities are free to express their criticisms and suggestions for FKUB.

In addition, FKUB also conducted verbal communication by means of written communication, such as books, magazines, newspapers, banners, billboards and so on. Verbal communication carried out by FKUB through books, magazines, newspapers contained invitations and appeals to follow the government regulations on guidelines for religious harmony, or appeals and invitations not to cause disruption and discord. Banners and billboards were verbal communication media used in certain occasions such as during local election or the commemoration of religious holidays. All of the above print media were FKUB's verbal tools in conveying the messages of harmony and tolerance for the citizens of Medan.

Non-verbal communication carried out by FKUB was in the form of public events such as interfaith sporting events, communal work, outbound program, interfaith speech contest, and interfaith writing contest. The above activities attempted to create the impression and deliver the message of togetherness that needs to be maintained and fostered for everyone's benefits. Through these activities, religious communities would understand the importance of tolerance and accept the differences as a paramount courtesy for the Indonesians.

Thus, FKUB's main objective in determining communicators in essence is to deliver more discernible messages of tolerance and harmony and to make it easier for FKUB to achieve their objectives of maintaining tolerance and togetherness in the midst of the citizens of Medan.

\section{b. Strategies in Determining Targets}

In every dialogue, FKUB categorized their targets into several sections based on the activities' themes, participants' age, sex, education, occupation, or religion in order to make it easier to determine what was needed in the activities.

The different targets would make it easy to determine what FKUB needed in delivering their messages of tolerance and harmony. Thus, determining the targets greatly determined the success of FKUB communication. If the targets had been determined, the needs could be easily determined as well. For example, interfaith dialogues involving leaders of religious communities would differ in their needs from dialogues among interfaith youth leaders. 
Likewise, the requirements for interfaith sporting events were different from those for highschool outbound activities.

Therefore, in implementing its communication strategy, FKUB would first determine their targets in their programs promoting harmony and tolerance such as dialogues with interfaith leaders, female figures, caretakers of place of worship, religious trainers, religious teachers, youths, university and high school students, and neighborhood chiefs.

Other FKUB programs included interfaith sporting events, communal work, highschool writing contests, high-school speech competition, and high-school outbound training. In these programs, FKUB first determined the targets in implementing their communication strategy. All these activities had varying needs; thus, the pre-determined objectives would determine the communication strategy applied by FKUB.

\section{c. Strategy in Organizing Messages}

According to Hafied Cangara, in organizing a message, it is necessary that the message be informative, persuasive, and educational. Therefore, in preparing their messages, FKUB always referred to the above principle. FKUB's communication message composition strategy is as follows (Hafied Cangara: 2013):

1) Informative

In the process of delivering messages, FKUB focused on disseminating actual and general information. Actual information delivered by FKUB included the messages of tolerance on religious holidays. For instance, in welcoming the holy month Ramadan, FKUB would disseminate the messages requesting the citizens to respect those who would fast. Similarly, on Christmas FKUB distributed the messages requesting the citizens to respect the celebrating religious community. Likewise, during the Chinese New Year celebration, FKUB also appealed for respect for celebrating religious communities.

Furthermore, the dissemination of messages of harmony and tolerance by FKUB was carried out in every opportunity through all available media. FKUB used not only print media in the form of newspapers, magazines, banners and billboards, but also social media such as websites, Facebooks, Twitter and Instagram, through which their messages could quickly spread into the community.

\section{2) Persuasive}

Messages disseminated by FKUB were mainly persuasive in tone. This means that every message of harmony and tolerance delivered by FKUB was expected to produce a change of understanding among the religious people in Medan. The persuasive message from FKUB was in the form of knowledge about the importance of maintaining harmony and tolerance in the midst of the people of Medan. Harmony and peace are extremely valuable and irreplaceable, and they are the initial assets for the further development of the city. On the contrary, hostility and conflict are the prelude to destruction and setbacks for the people of Medan.

Therefore, in every dialogue and discussion with interfaith leaders, for example, FKUB stressed the importance of their participation in maintaining the harmony in Medan. On another occasion in a dialogue with interfaith female leaders, FKUB also emphasized the message that women were highly influential in shaping their families' understanding of religious tolerance. A mother is able to instill tolerance and harmony in her family. In addition, women also have an influence in the midst of their community. Also, when they 
assume a position in her organization as a member or a leader, they will be an intermediary in propagating the importance of maintaining harmony and togetherness.

Persuasive messages were also disseminated by FKUB when conducting dialogues with interfaith worship place caretakers, religious counselors, teachers, youths, university students, high-school students, and neighborhood chiefs. Everyone was expected to contribute to create a conducive and progressive city of Medan. FKUB invited all layers of society to show mutual respect and tolerance, to promote equality and to value the differences for the common good. This was the persuasive message FKUB conveyed in every opportunity to instill the awareness of the religious communities in Medan.

3) Educating

Before composing their messages of tolerance, FKUB were very concerned about what and how the messages should be conveyed to the religious communities. Their messages contained appeals for tolerance and peace. For example, when holding dialogues and outdoor activities with interfaith high-school students, FKUB delivered some educational messages. Their objective was to impart the concept of harmony to the students who came from different religious backgrounds.

The concept of tolerance and harmony as understood by the younger generation was that to be the successors of this nation, they should not bring up the issue of the differences in religions and beliefs. In fact, all elements of the society need to contribute in order to achieve their shared objectives. This was well-reflected in the outbound programs for interfaith highschool students organized by FKUB. The students played games in teams consisting of various religious and ethnic groups. Thus, a sense of togetherness and unity could be nurtured within each student.

Another educating program by FKUB was the interfaith speech contest. Again, the students were invited to get to know and understand the background of all the speech participants. When the contest started, each participant was required to pay attention to the contents of the speech presented by the other participants. Mutually accepting and understanding the differences became the primary lesson for all the participants of the contest. Later on, each participant would first practice and rehearse the contents of his or her speech. Thus, the participants learned that they would become agents of harmony who will convey their understanding of tolerance and harmony both to their families and to fellow students.

\section{d. Strategy in Media Selection}

In selecting communication media, it is necessary to take into account the characteristics of and the purpose of the contents of the message as well as the type of media accessible to the public. Bearing this in mind, when relaying their messages, FKUB managed to deliver their messages well. Among the communication media often used by FKUB in conveying their messages include:

\section{1) Print Media}

Although classified as outdated, print media such as newspapers and magazines still have a special attraction for some audience to read. Newspapers are still read by certain people in society, especially in certain state and private institutions. FKUB used this opportunity to convey their messages to the religious communities in Medan. The message of harmony and tolerance propagated by FKUB, when conveyed by means of newspaper, became much more memorable and more easily accepted by the religious communities. 
Among the newspapers used by FKUB Medan in conveying their messages of tolerance and harmony were Harian Waspada, Harian Sumut Pos, Harian Analisa, Harian Medan Pos, etc. The messages were in the form of appeals and invitations for mutual respect and tolerance among religious adherents, respecting each other's differences in order to create peace in Medan.

In addition, FKUB also utilized certain occasions such as Regional Election, Religious Holidays and so on to spread their messages. At these moments, political tension and differences of opinion and choice could easily trigger social frictions. Therefore, FKUB's efforts to encourage the public not to be provoked by false news that could hurt the religious order in Medan became more important.

2) Electronic Media

In addition to printed media, FKUB also used electronic media as their communication channel. Electronic media still occupy an important position in the midst of the people of Medan. They are able to penetrate all levels of society from the middle and lower classes to upper middle class. In addition, electronic media are classified as up-to-date media that are able to educate wider audiences. Even though the cost was fairly expensive, it was still affordable for FKUB, and as a result, it became much easier for FKUB to disseminate their messages of tolerance and harmony.

Among the electronic media used by FKUB were television and radio. Television offered more advantages in terms of social interaction. It was used by FKUB for interactive services with religious communities. The audience were given an explanation on the importance of maintaining harmony and then invited to participate in a dialogue to voice their opinions. This interactive service was also carried out with representatives of interfaith audience in the studio. Radio was used by FKUB to communicate with the interfaith community interactively. Interfaith communities still use radio as a means of information in their houses. The two electronic media above are still able to educate the religious community at large. Thus, the messages of harmony delivered by FKUB could be more easily delivered. These communication channels greatly facilitated the role and function of FKUB Medan in disseminating information and knowing firsthand the demands and aspirations of the religious communities in Medan.

\section{3) Outdoor Media}

Other media also utilized by FKUB as its communication channel were outdoor media. The term outdoor media refers to the media installed and used outdoor and intended for public use. Among the outdoor media are banners, billboards and posters. These three media are installed to give a message directly to the audiences who view them. Although they can only be viewed from a close proximity, they were quite effective in educating the people of faith in the city of Medan.

The message of harmony delivered by FKUB Medan through these media was an appeal for mutual tolerance and mutual respect among fellow religious believers. It was disseminated moments before the elections, the celebration of the New Year, welcoming the holy month of Ramadan, or other religious holidays. In terms of cost, these outdoor media are relatively cheap depending on the number of the media created. The more banners were produced, the greater the fee was required.

4) Small format media

Small format media were also among FKUB's choice of communication channels in conveying their messages of harmony and tolerance to the religious community in the city of 
Medan. Among the small format media used by FKUB were brochures, stickers, and desk calendars. They were still considered important for the dissemination of information on FKUB Medan's programs and agenda. Every FKUB activity was photographed and printed on the FKUB calendar. In addition, an appeal for tolerance among religious adherents was also printed there. These media could be a complement to help channeling FKUB communication to places unreachable by other types of media.

Moreover, FKUB also used these channels to establish communications with such institutions as the city government of Medan, the High Court, the Capital City Police of Medan, the District Military Command, the Indonesian Ulema Council of Medan and other agencies. Using the small format media, FKUB were able to make sure that their messages were able to reach these institutions

\section{Conclusion}

The city of Medan which from the outset is well-known for its heterogeneous citizens who live side by side becomes safer with the presence FKUB as an institution that unites the differences. FKUB as a civic and social organization based on the equality and unity to purify the values of togetherness plays a very strategic role and function in safeguarding Medan from the looming potentials for conflicts. Economic, political and moral crises may very well have implications for social relations. In addition, social pressures and even social frustrations might affect the level of moral decline of the citizens of Medan. This phenomenon psychologically and sociologically influenced the social attitudes and behavior of the believers living in the city of Medan.

The diverse citizens of Medan who are able to live together in harmony and peace with mutual respect to each other have a major role in the development of the city of Medan. Therefore, FKUB with all of their efforts are very instrumental in maintaining the harmony among the religious communities and ensuring that all citizens can devote their potentials to contribute positively to the city of Medan.

\section{References}

Adiwijaya, S., et al.2018. Empowerment Pattern for Thalasemi Patients in Dr. Soetomo Hospital Surabaya (Study of the Association of Parents with Thalassemia Indonesia, Surabaya). Budapest International Research and Critics Institute-Journal (BIRCIJournal), 1(4): 289-298.

Batubara, M. U., Lubis, L., and Kholil, S. 2019. Islamic Communication Pattern of Judges in Dealing Conflict of Muslim Families in the Religious Court Medan. Budapest International Research and Critics Institute-Journal (BIRCI-Journal) (2): 373-386

Elvira SD, G H.2013. Buku Ajar Psikiatri. Jakarta: Badan Penerbit Fakultas Kedokteran Universitas Indonesia.

Idaiani S. (2015). Faktor Yang Paling Dominan Terhadap Pemasungan Orang Dengan Gangguan Jiwa Di Indonesia (Factors Contributing to Shackling Practice of Psychotic People in Indonesia).

Jacobs R, Gutacker N, Mason A, et al.2015. Determinants of hospital length of stay for people with serious mental illness in England and implications for payment systems: A regression analysis. BMC Health Serv Res;15(1):1-16. doi:10.1186/s12913-015-110769 
Kementerian Kesehatan. Peraturan Menteri Kesehatan Republik Indonesia No. 54 Tahun 2017 Tentang Penanggulangan Pemasungan Orang Dengan Gangguan Jiwa. 1-14. https://www.persi.or.id/images/regulasi/permenkes/pmk542017.pdf.

Kementrian Kesehatan RI.2008. Keputusan Menteri Kesehatan no129 tahun 2008 tentang standar pelayanan minimal rumah sakit.

Mawardi, Hasyimsyah, Drajat, A. 2019. Agenda Empowerment of People in Tarmizi Taher

Point of View. Budapest International Research and Critics Institute-Journal (BIRCI-Journal) (2): 443-450.

Nakanishi M, Niimura J, Tanoue M, Yamamura M, Hirata T, Asukai N.2015. Association between length of hospital stay and implementation of discharge planning in acute psychiatric inpatients in Japan. Int J Ment Health Syst. 9(1). doi:10.1186/s13033-0150015-Maramis WF. Catatan Ilmu Kedokteran Jiwa. 2nd ed. Airlangga University Press; 2009.

Newman L, Harris V, Evans LJ, Beck A.2018. Factors Associated with Length of Stay in Psychiatric Inpatient Services in London, UK. Psychiatr Q. 2018;89(1):33-43. doi:10.1007/s11126-017-9498-7Kementerian Kesehatan. Riset Kesehatan Dasar 2018.

Puteh I, Marthoenis M, Minas H.2011. Aceh Free Restraint: Releasing the mentally ill from physical restraint. Int J Ment Health Syst. 5:1-5. doi:10.1186/1752-4458-5-10

Rosdiana R.2018. Identifikasi Peran Keluarga Penderita dalam Upaya Penanganan Gangguan Jiwa Skizofrenia. Media Kesehat Masy Indones. 14(2):174. doi: $10.30597 / \mathrm{mkmi} . v 14 \mathrm{i} 2.3787$

Rumah Sakit Jiwa Aceh.2019. Rumah Sakit Jiwa Aceh Tahun 2018.

Saddock BJ.2010. Sinopsis Psikiati: Ilmu Pengetahuan Perilaku Psikiatri Klinis.

Suprayitno, Triyani, and Pratiwi, P. F. P. 2019. Strategy on the National Unity and Politics Agency (KESBANGPOL) in Maintaining Ethnicity and Religious Relations Based on Huma Betang Philosophy in Central Kalimantan. Budapest International Research and Critics Institute-Journal (BIRCI-Journal) (2): 229-238. 